\title{
Characterization and Safety Profile of Transfer Factors Peptides, a Nutritional Supplement for Immune System Regulation
}

\author{
Hudson Polonini ${ }^{1, *(0)}$, Any Elisa de Souza Schmidt Gonçalves ${ }^{2}$, Eli Dijkers ${ }^{1}$ and Anderson de Oliveira Ferreira ${ }^{1}$ \\ 1 Fagron B.V., Lichtenauerlaan 182, 3062 ME, Rotterdam, The Netherlands; eli.dijkers@fagron.com (E.D.); \\ anderson.ferreira@fagron.com (A.d.O.F.) \\ 2 Infinity Pharma Brasil, Av. Pierre Simon de Laplace, 751 Techno Park, Campinas, SP 13069-320, Brazil; \\ any.goncalves@infinitypharma.com.br \\ * Correspondence: hudson.polonini@fagron.com
}

Citation: Polonini, H.; Gonçalves, A.E.d.S.S.; Dijkers, E.; Ferreira, A.d.O Characterization and Safety Profile of Transfer Factors Peptides, a Nutritional Supplement for Immune System Regulation. Biomolecules 2021, 11, 665. https://doi.org/10.3390/ biom 11050665

Academic Editor: Anna Tinti

Received: 31 March 2021

Accepted: 27 April 2021

Published: 29 April 2021

Publisher's Note: MDPI stays neutral with regard to jurisdictional claims in published maps and institutional affiliations.

Copyright: (c) 2021 by the authors. Licensee MDPI, Basel, Switzerland. This article is an open access article distributed under the terms and conditions of the Creative Commons Attribution (CC BY) license (https:// creativecommons.org/licenses/by/ $4.0 /)$.

\begin{abstract}
Imuno $\mathrm{TF}^{\circledR}$ is a nutritional supplement composed of isolated transfer factors (TF) from porcine spleen. It is composed of a specific mixture of molecules that impact functions of the biological systems and historically is linked to the immune system regulation. In this study, we demonstrate for the first time its proteomic analysis, nutritional composition, and safety profile in terms of mutagenic potential and acute oral dose $\left(\mathrm{LD}_{50}\right)$. The obtained analysis indicated the product is a complex set of oligo- and polypeptides constituted of 163 different peptides which can potentially act on multiple mechanisms on the immune system pathways. The chemical composition showed low fat and low sugar content, saturated fatty acids-free, and the presence of 10 vitamins and 11 minerals. No mutagenic effect was observed, and the $\mathrm{LD}_{50}$ was $5000 \mathrm{mg} \mathrm{kg}^{-1}$ body weight. This accounts for a safe product to be used by the oral route, with potential benefits for the immune system.
\end{abstract}

Keywords: transfer factor; Imuno TF; safety profile; characterization; peptides; proteomics

\section{Introduction}

Imuno $\mathrm{TF}^{\circledR}$ is a nutritional supplement sold worldwide and composed of oligo- and polypeptides fractions from porcine spleen commonly referred to as transfer factors (TF) and with biological activity on immune regulation. They are produced by Thelper cells $[1,2]$ and are non-species-specific, i.e., TF produced in one species is effective in another animal species [1,3]. Although there are several pieces of evidence on its clinical effects [4,5], to date few studies have evaluated its molecular characterization.

Although having been in the global market for a long time, TFs are gaining a new momentum in scientific community. This is due to the growing body of evidence for their use in the improvement of health conditions, including viral infections caused by EpsteinBarr virus [6], herpes simplex virus (genital and labial) [7,8], herpes-zoster virus [9], human papillomavirus (HPV) [10], varicella-zoster virus (VZV) [4] and, more recently, SARS-CoV-2, the causal agent of COVID-19 [11].

The first mention of TF in the literature was in 1955, where it was demonstrated that leukocyte dialysis extract from a healthy donor-which presents a positive immune response confirmed through delayed hypersensitivity tests-was able to transfer to a healthy recipient and to also respond positively to this test [12]. In 1983, Lawrence and Borkowsky modified the original TF purification protocol using a dialysis membrane and a second molecular exclusion membrane to obtain molecules of three different sizes: $<3.5 \mathrm{kDa},>3.5 \mathrm{kDa}$, and $<12 \mathrm{kDa}$. This allowed them to identify the fraction that could bind to antigens: $3.5 \mathrm{kDa}$ and $12 \mathrm{kDa}$ [13]. In subsequent studies, Kirkpatrick and collaborators characterized these molecules as being small peptides, with molecular weight generally between $3.5 \mathrm{kDa}$ and $6.0 \mathrm{kDa}[14,15]$.

Since then, more studies have attempted to shine a light on the molecular structure of TF. There is evidence that TFs consist of short chains of amino acids with small pieces 
of ribonucleic acid (RNA) attached [16,17]. The RNA is probably related to a cytophilic property and the specificity of the TF [18], as the absence of the oligoribonucleotide linked to the amino termination of peptides results in loss of activity [7].

The length of the peptide chain of TFs is still under debate; there are reports of 17 or 18 amino acids present in TF $[19,20]$, with high tyrosine and glycine content [18], but given the molecular weight of the fractions, they could be even bigger molecules with 24 amino acids or more. Especially since, the molecular weight of tryptophan (the heaviest amino acid), for example, is more than $200 \mathrm{Da}$ [21].

It also needs to be taken into consideration that by nature, TFs extracts are complex mixtures, containing a high number of different TFs, and not just one single chemical entity [22]. In contrary to Imuno $\mathrm{TF}^{\circledR}$, other commercially available traditional TF extracts are generally obtained from cow colostrum (which can cause allergic reactions in other species due to the presence of immunoglobulins [23]), bird's egg yolks, or other tissue obtained from suitable animals $[18,22]$. Until now, little is known about the exact chemical composition of the TFs.

The objective of this study was to characterize Imuno $\mathrm{TF}^{\circledR}$ through proteomics analysis and to evaluate its safety profile through the determination of the mutagenic potential and acute oral toxic dose. Imuno $\mathrm{TF}^{\circledR}$ was chosen as it is derived from the porcine spleen, and therefore has a more favorable safety and efficacy profile compared to TFs from other sources, which may contain immunoglobulins [23].

\section{Materials and Methods}

\subsection{Samples}

To ensure meaningful results on chemical composition, samples $(30 \mathrm{~g})$ from three different batches of powdered Imuno $\mathrm{TF}^{\circledR}$ were supplied by Infinity Pharma Brasil (Campinas, SP, Brazil), a Fagron company (Rotterdam, The Netherlands).

\subsection{Nutritional Composition (Compositional Analysis)}

The nutritional composition of Imuno $\mathrm{TF}^{\circledR}$ was assessed through different methods: The AOAC International Official Methods of Analysis (OMA) procedures were followed as per published for fats (total, unsaturated, monounsaturated, polyunsaturated, and trans) [24] and cholesterol [25], both using gas chromatography (GC), and total dietary fiber by gravimetry [26]. Protein was determined by the classic Kjeldahl method (titrimetry), with no modifications as described by Instituto Adolfo Lutz [27]. Carbohydrates and amino acids were determined by high-performance liquid chromatography (HPLC) following the method described by Casterline et al., with no modifications [28]. Vitamins were determined using the official methods described in the United States Pharmacopeia (USP), using high-performance liquid chromatography (HPLC) [29]. Mineral composition content was determined by Inductively Coupled Plasma mass spectrometry (ICP-MS) using as reference the procedures described in Standard Methods and literature [30,31], but with modifications, as follows: aliquots were diluted to $25 \mathrm{~mL}$ with Milli-Q water and then injected into the nebulizer of the spectrometer by a peristaltic pump. Analyses were conducted under an argon plasma flux of $15 \mathrm{~mL} / \mathrm{min}$ at $26.00 \mathrm{MHz}$ with $40 \mathrm{~s}$ of sample uptake at $0.3 \mathrm{rps}$ and using a helium collision cell to selectively attenuate all polyatomic interferences based on their size.

\subsection{Proteomic Analysis}

Proteomic analysis was performed according to Martins-de-Souza et al. [32,33] and is briefly described below.

Protein extraction. Imuno $\mathrm{TF}^{\circledR}$ samples $(n=3)$ were solubilized in ammonium bicarbonate and digested in a 1:80 trypsin solution for $8 \mathrm{~h}$. The resulting peptides were analyzed using a two-dimensional Acquity M-Class nanoUPLC system (Waters Corporation, Milford, MA, USA), coupled to a Synapt G2-Si spectrometer (Waters Corporation, Milford, MA, USA). The MS and MS/MS data were obtained using data-independent 
acquisition (DIA) and ion mobility separation. The peptide samples derived from the three biological and technical triplicates (in 1\% formic acid) were analyzed using an HDMSE (high-definition data-independent mass spectrometry) employing a 54 min gradient in reverse-phase chromatography (linear gradient of 3-40\% ACN).

Protein identification and MS analysis. Peptides were loaded onto a nanoACQUITY UPLC HSS T3 Column (100 A, $1.8 \mu \mathrm{m}, 75 \mu \mathrm{m} \times 150 \mathrm{~m}$, Waters Corporation, Milford, MA, USA). Injections were performed using a nano-electrospray ionization source in positive ion mode (nanoESI (+), with a NanoLock-Spray (Waters, Manchester, United Kingdom) ionization source. A solution of [Glu1]-Fibrinopeptide B (Glu-Fib; Human) was used as the lock mass and was sampled every $30 \mathrm{~s}$. MS and MS/MS spectra were processed, and data searched in Progenesis QI for Proteomics 3.0 (Waters). In this process, the following parameters were considered: 5 as maximum peptide charge, maximum protein mass of $600 \mathrm{kDa}$, a maximum of 2 missed cleavages, at least 2 fragments per peptide, with a False Discovery Rate (FDR) FDR of $<1 \%$ and a mass error cutoff of $20 \mathrm{ppm}$. The tryptic digestion of a low molecular mass fraction can generate peptides with only one tryptic end; thus, data was searched using trypsin, Lys-C, and Arg-C as enzymes. Cysteine carbamidomethylation and methionine oxidation were considered as fixed and variable modifications, respectively. The database used was the Sus scrofa (Pig) UNIPROT databank.

\subsection{In Vitro Safety Profile: Mutagenic Potential}

Sample and controls. Imuno $\mathrm{TF}^{\circledR}$ was diluted in culture medium (CM) [DMEM, containing penicillin, streptomycin, L-glutamine, sodium pyruvate and $5 \%$ fetal bovine serum (FBS)] to $100 ; 10 ; 1 ; 0.1 ; 0.01 ; 0.001 ; 0.0001$, and $0.00001 \mathrm{mg} \mathrm{mL}^{-1}$ for cell viability and at $5,1.67$, and $0.56 \mathrm{mg} \mathrm{mL}^{-1}$ (with and without $\mathrm{S} 9$ metabolization) for micronucleus testing. Sodium dodecyl sulfate (SDS) was used as a positive control (starting concentration $=100 \mu \mathrm{g} \mathrm{mL}-1$ in $\mathrm{CM}$; seven solutions were prepared from the initial concentration, in dilution factor 1.47) for cell viability and cyclophosphamide $\left(20 \mu \mathrm{g} \mathrm{mL} \mathrm{m}^{-1}\right.$ in $\mathrm{CM}+5 \% \mathrm{FBS}$; in the tests with and without S9 metabolization) and colchicine $\left(0.1 \mu \mathrm{g} \mathrm{mL}^{-1}\right.$, in $\mathrm{CM}+5 \%$ FBS; long-term treatment, without metabolization) were used for the micronucleus test. $\mathrm{CM}$ was used as a negative control for both tests.

Cell viability. Cell viability test was conducted following the OECD guidelines [34] to identify the non-cytotoxic concentrations of $\operatorname{Imuno} \mathrm{TF}^{\circledR}$ to be used in the micronucleus test. The evaluation was performed using the method of sulforhodamine B and the protein quantification was determined spectrophotometrically. Briefly, lung cells of the Chinese hamster (V79-4) were incubated in a DMEM culture medium containing $10 \%$ of FBS and were kept under a $\mathrm{CO}_{2}$ atmosphere for approximately $24 \mathrm{~h}$. After the adaptation period, the cells were exposed to 8 concentrations of Imuno $\mathrm{TF}^{\circledR}$ for $24 \mathrm{~h}$. After this period, cells were submitted to morphologic analysis; then, the cells were fixated with $50 \%(v / v)$ trichloroacetic acid followed by refrigeration for $1 \mathrm{~h}$. The plates were submitted to five washings in running water for the removal of the trichloroacetic acid residues, culture medium, FBS, and secondary metabolites. After complete drying, the protein sulforhodamine B colorant was added at $0.4 \%(p / v)$ dissolved in acetic acid at $1 \%(v / v)$, and then, the plates were incubated at room temperature, for $10 \mathrm{~min}$. The wells were washed 5 times with acetic acid solution 1\% $(v / v)$ and, after the complete drying, the colorant connected to the cell proteins was solubilized with Tris Base solution $10 \mathrm{mM}$. Spectrophotometric reading at $515 \mathrm{~nm}$ was obtained for the determination of the $\mathrm{IC}_{50}$ using XLSTAT 2020 software.

In vitro micronucleus test (MNvit). V79-4 cells were incubated in a culture medium (DMEM, L-glutamine, sodium pyruvate, and 10\% FBS) for around $24 \mathrm{~h}$. After this period, the cells were treated with three concentrations of Imuno $\mathrm{TF}^{\circledR}$ for $3 \mathrm{~h}$, split into 2 groups: with or without S9-mix solution $\left(\mathrm{MgCl}_{2} / \mathrm{KCl}\right.$ solution; glucose 6-phosphate; NADP; S9 fraction and reverse osmosis water). After the treatment period, the culture medium was removed, and the cells from the group without the S9-mix solution were exposed to the cytochalasin B solution ( $3 \mu \mathrm{g} \mathrm{mL}{ }^{-1}$ in culture medium) for $21 \mathrm{~h}$ in the $\mathrm{CO}_{2}$ incubator. 
After this period, cell suspensions were obtained by centrifugation and the pellet was resuspended in refrigerated hypotonic solution for $3 \mathrm{~min}$. Then, methanol: acetic acid (3:1) fixative was added; the suspensions were centrifuged, and the pellet was resuspended in the fixative and again centrifuged-this step was then repeated one more time. The supernatant was discarded, leaving around $1 \mathrm{~mL}$ of fixative to resuspend the pellet. The cell suspension was dripped in two histological slides, previously cleaned, and kept in refrigerated reverse osmosis water. After drying, slides were cut with blue methylene eosin colorant (Giemsa/methanol) for $5 \mathrm{~min}$. After a quick washing in reverse osmosis water and drying of the slides, the optical microscopy analysis was started and of each Imuno $\mathrm{TF}^{\circledR}$ concentration tested, 2000 binucleated cells were counted. In this population, the incidence of multinucleated cells with 1,2,3, or 4 micronuclei was considered. In addition, the number of mononucleated and multinucleated cells was accounted for. With these experimental values, the CBPI (Cytokinesis-Block Proliferation Index), and the RI (Replication Index) were calculated, both to measure the cytotoxicity of the test items, and the percentage of binucleated cells with micronucleus (\%BCMN) for the evaluation of the mutagenic potential. Data obtained from the slides was analyzed using XLSTAT software, and an ANOVA followed by a post-test Tukey was conducted to analyze the difference between the treatments $(p<0.05)$.

\subsection{In Vivo Safety Profile: Median Lethal Dose (LD50)}

Animals. Six healthy young female (nulliparous and not pregnant) Wistar Hannover line (Rattus Norvegicus) rats, with a weight range of approximately $200 \mathrm{~g}$ were used. Upon arrival at the laboratory, animals were evaluated, randomized, placed in cages with 5 animals per sex, and allowed to acclimate for 5 days. During this period, animals were observed by a veterinarian for general health and mortality. During the $24 \mathrm{~h}$ duration of the experiment, animals were housed individually. This experiment was conducted following the OECD guidelines [35] and supported by Protocol No. 004/20, approved by the Ethics Committee on the Use of Animals (CEUA) on 06/04/2020.

Acute oral dose. Animals were tested in a stepwise procedure with three female animals per step. A starting dose of $2000 \mathrm{mg} \mathrm{kg}^{-1}$ of body weight (bw) was used. Before the administration of Imuno $\mathrm{TF}^{\circledR}$, animals were fasted overnight by depriving food; water was supplied normally. After 3-4 h of Imuno $\mathrm{TF}^{\circledR}$ administration, animals were allowed food again. Imuno $\mathrm{TF}^{\circledR}$ was diluted in water and administered as a single dose by oral gavage. The treated animals revealed no clinical signs on Day 1 and no mortality was observed. Then, a confirmation study (with an again single dose of $2000 \mathrm{mg} \mathrm{kg}^{-1}$ bw Imuno $\mathrm{TF}^{\circledR}$ ) was run in another 3 rats, $24 \mathrm{~h}$ after the first dose had been administered. After dosing, all animals were evaluated at least once during the first $30 \mathrm{~min}$, and then periodically during the first $24 \mathrm{~h}$, with special attention during the first $4 \mathrm{~h}$ after administration. After $24 \mathrm{~h}$, the animals were evaluated daily for 14 days. All changes observed during this period were systematically recorded, and individual records were maintained for each animal. The observations included: changes in the skin and hair, eyes, and mucous membranes and the respiratory, circulatory, autonomic, and central nervous system, somatomotor activity, and behavioral pattern. Special attention was given to the appearance of tremors, convulsion, salivation, diarrhea, lethargy, drowsiness, or coma. If any sign of suffering and stress was observed, animals were euthanized. In cases of euthanized animals, as well as in the case of dead animals, the time of death was precisely recorded. The animals were weighed before the administration of the test item (Day 0 ) and on days 7 and 14 . At the beginning of the experiment, the bodyweight variation must not exceed $20 \%$ of the weighted average. At the end of the study, the surviving animals were euthanized in a $\mathrm{CO}_{2}$ chamber. The second method of euthanasia (cervical displacement) was performed to confirm the death of the animal. All animals were submitted to necropsy whenever possible. This included a careful examination of the outer surface of the body, all orifices, chest, pelvic, and abdominal cavity, and their contents. The observed macroscopic changes were recorded. For a more detailed verification of the toxicity, an autopsy was performed, and their organs were extracted for 
histopathological evaluation. The collected organs were stored in $10 \%$ formalin and then slides for evaluation were made. The organs collected were the brain, spinal cord, stomach, large and small intestine, liver, kidneys, adrenals, spleen, lung, heart, thymus, ovaries, vagina, bladder, and lymph node). Any observed microscopic changes were recorded.

\section{Results}

\subsection{Nutritional Composition}

The nutritional composition of Imuno $\mathrm{TF}^{\circledR}$ can be found in Table 1.

Table 1. Nutritional composition of Imuno $\mathrm{TF}^{\circledR}$.

\begin{tabular}{|c|c|c|}
\hline Energy & Value per $100 \mathrm{mg}$ & Reference Intake [36] \\
\hline Energy value & $0.321 \mathrm{Kcal} / 1347 \mathrm{KJ}$ & $2000 \mathrm{Kcal}$ \\
\hline General Components & Amount (mg per $100 \mathrm{mg}$ ) & Reference intake \\
\hline Total fat & $<0.3$ & $70 \mathrm{~g}$ \\
\hline & of which & \\
\hline - saturated fat & $<0.01$ & $20 \mathrm{~g}$ \\
\hline - monounsaturated fat & $<0.01$ & - \\
\hline - polyunsaturated fat & $<0.01$ & - \\
\hline - trans fat & $<0.002$ & - \\
\hline - cholesterol & $<0.002$ & - \\
\hline \multirow{2}{*}{ Total carbohydrates } & & $260 \mathrm{~g}$ \\
\hline & of which & \\
\hline - starch & $<0.09$ & - \\
\hline - fructose & $<0.1$ & - \\
\hline - glucose & $<0.1$ & - \\
\hline - sucrose & $<0.1$ & - \\
\hline- maltose & $<0.1$ & - \\
\hline - lactose & $<0.2$ & - \\
\hline - sorbitol & $<0.1$ & - \\
\hline Fiber & 0.5 & - \\
\hline \multirow[t]{2}{*}{ Protein } & 63.97 & $50 \mathrm{~g}$ \\
\hline & of which (amino acids) & \\
\hline - aspartic acid & 2.95 & - \\
\hline - glutamic acid & 5.19 & - \\
\hline - serine & 1.89 & - \\
\hline - histidine & 0.93 & - \\
\hline - glycine & 3.06 & - \\
\hline - threonine & 1.41 & - \\
\hline - arginine & 4.16 & - \\
\hline - alanine & 0.50 & - \\
\hline - tyrosine & 1.83 & - \\
\hline - cystine & $<0.1$ & - \\
\hline - valine & 1.30 & - \\
\hline - methionine & 1.17 & - \\
\hline - phenylalanine & 0.06 & - \\
\hline - isoleucine & 0.96 & - \\
\hline - leucine & 1.39 & - \\
\hline - lysine & 3.49 & - \\
\hline - proline & 0.10 & - \\
\hline Salt (sodium) & 0.7 & $6 \mathrm{~g}$ \\
\hline
\end{tabular}


Table 1. Cont.

\begin{tabular}{ccc}
\hline Energy & Value per 100 mg & Reference Intake [36] \\
\hline Specific Components & Amount (per 100 mg) & $\begin{array}{c}\text { Nutrient Reference Value } \\
\text { (NRV) }\end{array}$ \\
\hline Vitamins and minerals & & \\
Vitamin A & $<0.0005 \mu \mathrm{g}$ & $800 \mu \mathrm{g}$ \\
Vitamin B1 & $<0.0004 \mathrm{mg}$ & $1.1 \mathrm{mg}$ \\
Vitamin B2 & $0.00074 \mathrm{mg}$ & $1.4 \mathrm{mg}$ \\
Vitamin B3 & $0.00002 \mathrm{mg}$ & $16 \mathrm{mg}$ \\
Vitamin B6 & $0.00645 \mathrm{mg}$ & $1.4 \mathrm{mg}$ \\
Vitamin B9 & $<0.42 \mu \mathrm{g}$ & $200 \mu \mathrm{g}$ \\
Vitamin B12 & $<0.004 \mu \mathrm{gg}$ & $2.5 \mu \mathrm{g}$ \\
Vitamin C & $0.02 \mathrm{mg}$ & $80 \mathrm{mg}$ \\
Vitamin E & $<0.0002 \mu \mathrm{gg}$ & $12 \mathrm{mg}$ \\
Vitamin E (alfa-tocopherol) & $<0.00035 \mathrm{mg}$ & - \\
Potassium & $1.91 \mathrm{mg}$ & $2,000 \mathrm{mg}$ \\
Calcium & $0.028 \mathrm{mg}$ & $800 \mathrm{mg}$ \\
Phosphorous & $0.72 \mathrm{mg}$ & $700 \mathrm{mg}$ \\
Magnesium & $0.078 \mathrm{mg}$ & $375 \mathrm{mg}$ \\
Iron & $0.099 \mathrm{mg}$ & $14 \mathrm{mg}$ \\
Zinc & $0.0093 \mathrm{mg}$ & $10 \mathrm{mg}$ \\
Copper & $0.0065 \mathrm{mg}$ & $1 \mathrm{mg}$ \\
Manganese & $0.00011 \mathrm{mg}$ & $2 \mathrm{mg}$ \\
Selenium & $0.0011 \mathrm{mcg}$ & $55 \mathrm{mcg}$ \\
Chromium & $<0.000005 \mathrm{mcg}$ & $40 \mathrm{mcg}$ \\
Molybdenum & $0.019 \mathrm{mcg}$ & $50 \mathrm{mcg}$ \\
\hline
\end{tabular}

Reference intake of an average adult $(8400 \mathrm{~kJ} / 2000 \mathrm{kcal})$.

\subsection{Proteomic Analysis}

The characterized proteins identified on Imuno $\mathrm{TF}^{\circledR}$ are described in Table 2. The proteomic analysis revealed a total of 163 peptides associated with 23 distinct Sus scrofa (Pig) proteins. Two out of the 23 identified proteins are still uncharacterized, meaning the existence of these proteins was predicted in silico and no functional studies have been conducted thus far. Peptides' composition varied from 4 to 34 amino acids. The protein (or peptides from protein) with the highest prevalence in the sample are hemoglobin and globin domain (Table 2). Additionally, peptides from proteins that are known to interact with the immune system were identified: Talin-1, Ubiquitin-40S ribosomal protein S27a (aka 40S ribosomal protein S27a), and Ubiquitin-60S ribosomal protein L40.

\subsection{In Vitro Safety Profile: Mutagenic Potential}

Cell viability was determined in terms of half-maximal inhibitory concentration $\left(\mathrm{IC}_{50}\right)$. The IC50 value found for Imuno $\mathrm{TF}^{\circledR}$ was $11.6 \mathrm{mg} \mathrm{mL}^{-1}$. From the results of the cell viability test, $0.56,1.67$, and $5.0 \mathrm{mg} \mathrm{mL}^{-1}$ were selected for the evaluation of the mutagenic potential in the in vitro micronucleus test. The $\mathrm{pH}$ obtained for the highest concentration was 7.5. Positive control (SDS) presented $\mathrm{IC}_{50}$ was equal to $39.6 \mu \mathrm{g} \mathrm{mL}{ }^{-1}$ with a $\mathrm{pH}$ of 7.5.

In addition to the viability test, the cytotoxic and cytostatic activity of the treatments concerning the negative control items was evaluated from the values of CBPI and RI (Table 3). The CBPI indicates the mean number of cycles that each cell suffers during an exposure period to cytochalasin B and may be used to calculate the cell proliferation. In addition, the RI indicates the relative number of nuclei in treated cells, in comparison with the negative control item of the cultures and may be used to calculate the percentage of cytostatic cells that correspond to the inhibition of cell growth. Thus, the RI is a form of comparison of the number of binucleated or multinuclear cells that are found in the division process, and the higher its value, the smaller is the number of cytostatic cells, consequently, the lower will be the cytotoxicity of the test item. 
Table 2. Proteomic analysis of Imuno $\mathrm{TF}^{\circledR}$.

\begin{tabular}{|c|c|c|}
\hline Proteome Identifier (UPID) & Gene Name & Description \\
\hline P01965 & HBA & Hemoglobin subunit alpha \\
\hline P02067 & HBB & Hemoglobin subunit beta \\
\hline P02067 & HBB & Hemoglobin subunit beta \\
\hline F1SFZ8 & TLN1 & Talin-1 \\
\hline A0A287AZA7 & RPS27A & $\begin{array}{l}\text { 40S ribosomal protein S27a (Ubiquitin-40S ribosomal } \\
\text { protein S27a) }\end{array}$ \\
\hline A0A5K1UHC4 & AGPAT5 & PlsC domain-containing protein \\
\hline P01965 & HBA & Hemoglobin subunit alpha \\
\hline Q06AT1 & HPCA & Neuron-specific calcium-binding protein hippocalcin \\
\hline A0A480JNE4 & FAM184A & Protein FAM184A isoform 1 \\
\hline P49756 & RBM25 & RNA-binding protein 25 \\
\hline P09571 & $\mathrm{TF}$ & Serotransferrin \\
\hline Q8WXA9 & SREK1 & Splicing regulatory glutamine/lysine-rich protein 1 \\
\hline Q96A84 & EMD1 & EMI domain-containing protein \\
\hline A0A287AAR0 & GIMAP7 & AIG1-type G domain-containing protein \\
\hline A0A287AHD6 & LOC100622504 & Uncharacterized protein \\
\hline P00819 & ACYP2 & Acylphosphatase-2 \\
\hline P63053 & UBA52 & Ubiquitin-60S ribosomal protein $\mathrm{L} 40$ \\
\hline P13796 & LCP1 & Plastin-2 \\
\hline A0A5G2Q920 & ENSSSCG00000049439 & Uncharacterized protein \\
\hline Q99873 & PRMT1 & Protein arginine N-methyltransferase 1 \\
\hline A0A287AL08 & TAFA2 & $\begin{array}{c}\text { Protein FAM19A2 isoform X1/ Chemokine-like protein } \\
\text { TAFA-2 }\end{array}$ \\
\hline A0A5G2QDH3 & ENSSSCG00000051012 & Reverse transcriptase domain-containing protein \\
\hline F1SVA9 & SH2D6 & SH2D6 (signal transductor) \\
\hline
\end{tabular}

Table 3. Values concerning the CBPI, RI, and \%BCMN of Imuno $\mathrm{TF}^{\circledR}$ after the $3 \mathrm{~h}$ and $24 \mathrm{~h}$ treatments.

\begin{tabular}{|c|c|c|c|c|c|}
\hline Condition & $\begin{array}{c}\text { Negative Control } \\
(100 \%)\end{array}$ & $\begin{array}{l}\text { Positive Control } \\
\left(20 \mu \mathrm{g} \mathrm{mL}^{-1}\right)\end{array}$ & $\begin{array}{c}\text { Imuno } \text { TF }^{\circledR} \\
\left(5 \mathrm{mg} \mathrm{mL}^{-1}\right)\end{array}$ & $\begin{array}{c}\text { Imuno } \mathrm{TF}^{\circledR} \\
\left(1.67 \mathrm{mg} \mathrm{mL}^{-1}\right)\end{array}$ & $\begin{array}{c}\text { Imuno } \mathrm{TF}^{\circledR} \\
\left(0.56 \mathrm{mg} \mathrm{mL}^{-1}\right)\end{array}$ \\
\hline \multicolumn{6}{|l|}{$3 h, S 9-$} \\
\hline CBPI & $1.93 \pm 0.002$ & $1.92 \pm 0.004$ & $1.93 \pm 0.008$ & $1.93 \pm 0.002$ & $1.93 \pm 0.003$ \\
\hline RI (\%) & $100.00 \pm 0.00$ & $99.25 \pm 0.74$ & $99.65 \pm 0.65$ & $99.94 \pm 0.05$ & $99.94 \pm 0.57$ \\
\hline$\% B C M N$ & $1.85 \pm 0.07$ & $1.85 \pm 0.07$ & $2.15 \pm 0.07$ & $2.05 \pm 0.07$ & $1.85 \pm 0.07$ \\
\hline \multicolumn{6}{|l|}{$3 h$, S9+ } \\
\hline CBPI & $1.91 \pm 0.016$ & $1.90 \pm 0.002$ & $1.89 \pm 0.004$ & $1.92 \pm 0.007$ & $1.91 \pm 0.006$ \\
\hline RI (\%) & $100.00 \pm 0.00$ & $98.84 \pm 1.92$ & $98.20 \pm 2.16$ & $101.11 \pm 0.98$ & $99.81 \pm 1.16$ \\
\hline$\% B C M N$ & $2.00 \pm 0.00$ & $5.00 \pm 0.14^{*}$ & $2.15 \pm 0.07$ & $2.05 \pm 0.07$ & $1.95 \pm 0.07$ \\
\hline \multicolumn{6}{|l|}{$24 \mathrm{~h}, \mathrm{~S} 9-$} \\
\hline CBPI & $1.94 \pm 0.020$ & $1.66 \pm 0.005$ & $1.85 \pm 0.022$ & $1.91 \pm 0.007$ & $1.93 \pm 0.007$ \\
\hline RI (\%) & $100.00 \pm 0.00$ & $70.87 \pm 0.97$ & $90.93 \pm 0.35$ & $97.26 \pm 1.35$ & $98.75 \pm 1.39$ \\
\hline$\% B C M N$ & $1.85 \pm 0.07$ & $6.55 \pm 0.35 *$ & $2.45 \pm 0.07$ & $2.25 \pm 0.07$ & $2.05 \pm 0.07$ \\
\hline
\end{tabular}

${ }^{*} p<0.05$ concerning negative control item. Results expressed as mean of the replicates \pm standard deviation; Negative Control Item: cells containing only culture medium; Positive Control Items: Cyclophosphamide $(3 \mathrm{~h})$ and Colchicine $(24 \mathrm{~h})$; S9-: without S9 metabolization; S9+: with S9 metabolization; CBPI: Cytokinesis-Block Proliferation Index; RI: Replication Index; \%BCMN: percentage of binucleated cells with micronucleus.

The CPBI and RI values of the concentrations of the test item and the positive control item were within the acceptance criteria defined by the test guide for both the $3 \mathrm{~h}$ treatment and the $24 \mathrm{~h}$ treatment. In the mutagenicity test, CBPI and RI values were above 1.6 and $70 \%$, respectively, confirming the absence of cytotoxicity in the concentrations of the evaluated items.

For the experimental model with metabolic activation, the post-mitochondrial fraction (S9 fraction) was included. The results of BCMN percentage obtained with the use of the S9 fraction (S9+) combined with those of the experiment without S9 (S9-) allow to determine if the Imuno $\mathrm{TF}^{\circledR}$ tested is mutagenic in its original form (percentage values of 
BCMN similar in both experiments), if it becomes mutagenic after metabolization (values of BCMN S9+ are higher than BCMN S9-) or if generated metabolites are less mutagenic (values of BCMN S9- are higher than BCMN S9+) [34]. For Imuno TF ${ }^{\circledR}$, it was shown that both in systems with and without $\mathrm{S} 9$ metabolization, there was no statistically significant increase in the percentage of MN (Table 3) for the duration of 3 or $24 \mathrm{~h}$.

\subsection{In Vivo Safety Profile: Median Lethal Dose (LD50)}

Table 4 shows the weights of animals (g) during the study and the mortality index. No weight loss was observed in the tested animals during the study period. No macroscopic finding was observed after necropsy, both on external and visceral examination of terminally sacrificed rats. The microscopic evaluation revealed preserved organs and no abnormalities. It must be considered that the analyzed tissues did not show signs of toxic lesions, necrotic conditions, or inflammatory lesions (tissues preserved before the morphological evaluation). In the absence of any pathological injury in terminally sacrificed rats, it is concluded that the test item did not produce any treatment-related effect at the dose level.

Table 4. Weights of animals and mortality index for the Imuno $\mathrm{TF}^{\circledR}$ evaluation of the oral acutedose toxicity.

\begin{tabular}{cccccc}
\hline \multirow{2}{*}{ Experiment } & \multirow{2}{*}{$\begin{array}{c}\text { Animal } \\
\text { Number }\end{array}$} & Day 0 & Day 7 & Day 14 & $\begin{array}{c}\text { Mortality } \\
\text { Index (\%) }\end{array}$ \\
\cline { 3 - 5 } & 1 & 225 & 240 & 251 & \\
1 & 2 & 204 & 230 & 237 & $0.0 *$ \\
& 3 & 185 & 197 & 207 & \\
\hline \multirow{2}{*}{2} & 1 & 167 & 185 & 192 & $0.0 *$ \\
& 2 & 191 & 211 & 229 & \\
\hline
\end{tabular}

* No clinical sign was observed in any animal during the 14 days, nor pathologic (macroscopic) or histopathologic (microscopic: toxic lesions, necrotic conditions, or inflammatory lesions) findings on the skin, brain, eyes, lungs, heart, liver, spleen, urinary system, intestines, reproductive tract and body as a whole. Dose of $2000 \mathrm{mg} \mathrm{kg}^{-1} \mathrm{bw}$.

\section{Discussion}

Stimulation of the immune response, without disturbing its function can be obtained by the use of immunologically active substances localized in the lymphoid tissues and/or non-lymphoid origin, particularly those in the spleen. The spleen is the source of a large amount of biologically active substances, as well as protein factors that can enhance the humoral immune response and its inhibition [37].

Imuno $\mathrm{TF}^{\circledR}$ is an ultra-purified extract from the porcine spleen, and its nutritional composition shows that it contains at least 10 different types of vitamins and 11 minerals, from which two have well-established roles contributing to the normal function of the immune system (selenium and zinc) [38,39]. It is also a supplement with high content of protein and low quantities of fat and carbohydrates, and therefore can be considered low fat, saturated fatty acids-free, and low sugar product [40].

Understanding the composition of this nutrient allows us to associate the characterization with its biological function. The amino acids found in Imuno $\mathrm{TF}^{\circledR}$ are composed of at least 163 peptides, indicating that Imuno $\mathrm{TF}^{\circledR}$ is a complex set of peptides. Possibly, this is even an underestimation. A higher number could be present, as the high abundance of some peptides can mask the presence of others occurring in smaller quantities. As expected, a product derived from the spleen presents, also, a considerable amount of cell debris or blood-derived proteins. Each peptide identified appears to be a composition ranging from 4 to 34 amino acids (after digestion for the analysis), but bigger chains are expected, as the molecular size observed ranged between $402 \mathrm{Da}$ and $3463 \mathrm{Da}$. This is in line with the filtration cutoff of 10,000 Da used during the preparation of Imuno $\mathrm{TF}^{\circledR}$, which would allow for much larger di-, tri-, or polypeptides to be present in the $\operatorname{Imuno} \mathrm{TF}^{\circledR}$ extract. The 
peptides found in the sample were most linked to hemoglobin subunits alpha and beta. These proteins have high concentrations in the blood and can be released from red blood cells (erythrocytes), which are lysed during the purification and isolation process.

The most prominent protein acting on the immune system based on concentration in the sample and function is Talin-1. Talin- 1 has been one of the first proteins shown to be recruited to the immunological synapse formed between T lymphocytes and APCs to facilitate $\mathrm{T}$ cell activation [41]. Supported by this function, transfer factors may mediate indirectly the innate immune response.

The addition of this set of peptides to the Reactome Knowledgebase [42] allowed for the identification of possible 17 pathways to which TF components could play a role. Specifically for the immune system, the identified theoretical pathways were observed for both innate and adaptative responses, as well as for the cytokine signaling: the endoplasmic reticulum (ER)-phagosome, the receptor-type tyrosine-protein kinase (FLT3) signaling, the interleukin (IL)-17 signaling, the non-canonical NF- $\mathrm{kB}$ pathway, and the mitogen-activated protein kinase (MAPK) pathway.

The impact of TF on the phagocytic activities of the immune system was already reported [18], then the ER originated phagosomes can explain, at least partially, how antigens from intracellular pathogens such as a virus can be presented by MHC class I molecules [43]. The role of NF-kB was also reported as an inhibitory effect [44]. If those effects are confirmed, a role in immunoregulation could be accounted to TF-for example, through the effect on IL-17, which mediates inflammation for microbial clearance, but if overstimulated can promote immunopathology [45]. MAPK and FLT3 are also involved in inflammation and regulation of dendritic cells, respectively [46,47].

In addition, two associated proteins were uncharacterized. The existence of these proteins was predicted in silico and no functional studies have been conducted thus far. Therefore, further studies to investigate their biological function, possibly on the immune system, are to be considered.

Together with the characterization of Imuno $\mathrm{TF}^{\circledR}$, its safety was also evaluated. Under the conditions evaluated in this study, Imuno $\mathrm{TF}^{\circledR}$ did not present mutagenic potential at the concentrations of $5,1.67$, and $0.56 \mathrm{mg} \mathrm{mL}^{-1}$ in the systems studied, with and without metabolization, therefore it is considered safe in terms of possible interactions with the cell's DNA. Moreover, reviewing the acute oral toxicity results, it can be concluded that Imuno $\mathrm{TF}^{\circledR}$ at $2000 \mathrm{mg} \mathrm{kg}^{-1}$ bw dose can be classified as GHS Category 5 ("not classified", according to the Globally Harmonized System of Classification and Labeling of Chemicals, GHS) [35], with an LD 50 cut-off value in female Wistar rats of $5000 \mathrm{mg} \mathrm{kg}^{-1} \mathrm{bw}$ (classification goes from category 1 , higher toxicity, to category 5 , non-detectable toxicity). The recommended oral dose of Imuno $\mathrm{TF}^{\circledR}$ ranges from 50 to $100 \mathrm{mg}$, daily (equivalent to 0.7 to $1.4 \mathrm{mg} \mathrm{kg}^{-1} \mathrm{bw}$ for a $70 \mathrm{~kg}$ weighing adult). This implies that Imuno $\mathrm{TF}^{\circledR}$ is safe to use at the recommended dose.

\section{Conclusions}

$\mathrm{TF}$ isolated from porcine spleen (Imuno $\mathrm{TF}^{\circledR}$ ) can be characterized as a complex set of oligo- and polypeptides and is low fat, saturated fatty acids-free, and low sugar food supplement which contains vitamins and minerals. It can be considered safe for oral use and presents no mutagenic potential. Finally, its composition accounts for possible multiple mechanisms on the immune system pathways.

Author Contributions: Conceptualization, methodology, investigation, writing—original draft preparation, H.P. and A.E.d.S.S.G.; writing-review and editing, E.D. and A.d.O.F. All authors have read and agreed to the published version of the manuscript.

Funding: This research was entirely funded by Fagron B.V.

Institutional Review Board Statement: Animal experiments were conducted following the OECD guidelines [35] and supported by Protocol No. 004/20, approved by the Ethics Committee on the Use of Animals (CEUA) on 06/04/2020. 
Informed Consent Statement: Not applicable.

Conflicts of Interest: The authors work for Fagron, who funded the study. The funder had no role in the design of the study, nor in the collection, analyses, or interpretation of data.

\section{References}

1. Fudenberg, H.H.; Fudenberg, H.H. Transfer factor: Past, present and future. Annu. Rev. Pharmacol. Toxicol. 1989, 29, 475-516. [CrossRef]

2. Welch, T.M.; Wilson, G.B.; Fudenberg, H.H. Human transfer factor in guinea pigs: Further studies. In Transfer Factor; Academic Press: Cambridge, MA, USA, 1976; pp. 399-408.

3. Wilson, G.B.; Poindexter, C.; Fort, J.D.; Ludden, K.D. Specific pathogen-free and standard commercial chickens as models for evaluating xenogenic transfers of cell-mediated immunity. In Proceedings of the Fifth International Symposium on Transfer Factor, Bratislava, Slovakia, 10-13 November 1987; pp. 257-274.

4. Steele, R.W.; Myers, M.G.; Vincent, M.M. Transfer factor for the prevention of varicella-zoster infection in childhood leukemia. N. Engl. J. Med. 1980, 303, 355-359. [CrossRef]

5. Viza, D.; Pizza, G.; De Vinci, C.; Brandi, G.; Ablashi, D. Transfer Factor as an Option for Managing the COVID-19 Pandemic. Folia Biol. 2020, 66, 86-90.

6. Jones, J.; Jeter, W.; Fulginiti, V.; Minnich, L.; Pritchett, R.; Wedgwood, R. Treatment of childhood combined epstein-barr virus/cytomegalovirus infection with oral bovine transfer factor. Lancet 1981, 318, 122-124. [CrossRef]

7. Viza, D.; Fudenberg, H.H.; Palareti, A.; Ablashi, D.; De Vinci, C.; Pizza, G. Transfer factor: An overlooked potential for the prevention and treatment of infectious diseases. Folia Biol. 2013, 59, 53.

8. Pizza, G.; Viza, D.; De Vinci, C.; Palareti, A.; Cuzzocrea, D.; Fornarola, V.; Baricordi, R. Orally administered HSV-specific transfer factor (TF) prevents genital or labial herpes relapses. Biotherapy 1996, 9, 67-72. [CrossRef] [PubMed]

9. Estrada-Parra, S.; Nagaya, A.; Serrano, E.; Rodriguez, O.; Santamaria, V.; Ondarza, R.; Chavez, R.; Correa, B.; Monges, A.; Cabezas, R.; et al. Comparative study of transfer factor and acyclovir in the treatment of herpes zoster. Int. J. Immunopharmacol. 1998, 20, 521-535. [CrossRef]

10. Acosta-Rios, M.P.; Sauer-Ramírez, E.; Castro-Muñoz, L.J.; García-Solís, M.; Gómez-García, C.; Ocadiz-Delgado, R.; MartinezMartinez, A.; Sánchez-Monroy, V.; Pérez-De la Mora, C.; Correa-Meza, B.; et al. Effect of Dialyzable Leukocyte extract on chronic cervicitis in patients with HPV infection. J. Med. Life 2017, 10, 237-243. [PubMed]

11. Hernández, M.D.; Urrea, J.; Bascoy, L. Evolution of COVID-19 patients treated with ImmunoFormulation, a combination of nutraceuticals to reduce symptomatology and improve prognosis: A multi-centred, retrospective cohort study. medRxiv 2020. [CrossRef]

12. Lawrence, H.S. The transfer in humans of delayed skin sensitivity to streptococcal M substance and to tuberculin with disrupted leucocytes. J. Clin. Invest. 1955, 34, 219-230. [CrossRef]

13. Lawrence, H.S.; Borkowsky, W. A new basis for the immunoregulatory activities of transfer factor-an arcane dialect in the language of cells. Cell. Immunol. 1983, 82, 102-116. [CrossRef]

14. Kirkpatrick, C.H. Structural nature and functions of transfer factors. Proc. Natl. Acad. Sci. USA 1993, 685, 362-368. [CrossRef] [PubMed]

15. Rozzo, S.J.; Kirkpatrick, C.H. Purification of transfer factors. Mol. Immunol. 1992, 29, 167-182. [CrossRef]

16. Kirkpatrick, C.H. Activities and characteristics of transfer factors. Biotherapy 1996, 9, 13-16. [CrossRef] [PubMed]

17. Berrón-Pérez, R.; Chávez-Sánchez, R.; Estrada-García, I.; Espinosa-Padilla, S.; Cortez-Gómez, R.; Serrano-Miranda, E.; Portugués, A. Indications, usage, and dosage of the transfer factor. Rev. Alerg. Mex. 2007, 54, 134-139. [PubMed]

18. Krishnaveni, M. A review on transfer factor an immune modulator. Drug Invent. Today 2013, 5, 153-156. [CrossRef]

19. Liu, H.; Zhang, R.; Wu, Y.; Wang, Y.; Che, H. Determination of free amino acids in transfer factor capsules by pre-column derivatization with RP-HPLC. Chin. J. Biochem. Pharm. 2007, 28, 233-235.

20. Wang, G.; Zhao, C.; Wang, L.; Zhang, P. Basic research on physicochemical properties of three transfer factors. J. Jilin Univ. 1990, $16,432-435$.

21. White, A. Transfer Factors E Immune System Health, 2nd ed.; BookSurge Publishing: Charleston, SC, USA, 2009.

22. Hennen, W.J. The transfer factor report. In Transfer Factor: Natural Immune Booste; Woodland Publishing: Salt Lake City, UT, USA, 1998; pp. 1-32.

23. Bernhisel-Broadbent, J.; Yolken, R.H.; Sampson, H.A. Allergenicity of orally administered immunoglobulin preparations in food-allergic children. Pediatrics 1991, 87, 208-214.

24. AOAC International. AOAC International. AOAC official method 996.06: Fat (total, saturated, and unsaturated) in foods. In Official Methods of Analysis; Association of Official Analytical Chemists: Washington, DC, USA, 2019.

25. AOAC International. AOAC International. AOAC official method 994.10: Cholesterol in foods. In Official Methods of Analysis; Association of Official Analytical Chemists: Washington, DC, USA, 2019.

26. AOAC International. AOAC International. AOAC official method 991.43: Total, soluble, and insoluble dietary fibre in foods. In Official Methods of Analysis; Association of Official Analytical Chemists: Washington, DC, USA, 2019.

27. Instituto Adolfo Lutz. Método de Kjeldahl clássico. In Métodos Físico-Químicos para Análise de Alimentos; Instituto Adolfo Lutz: Sao Paulo, Brazil, 2008; pp. 123-124. 
28. Casterline, J.L.; Oles, C.J.; Ku, Y. Measurement of sugars and starches in foods by a modification of the AOAC total dietary fiber method. J. AOAC Int. 1999, 82, 759-765. [CrossRef]

29. United States Pharmacopeial Convention. USP 40-NF 35 The United States Pharmacopeia and National Formulary; United States Pharmacopeial Convention Inc.: Rockville, MD, USA, 2017.

30. De Paula, L.N.; de Oliveira, I.N.; Pires, T.O.; Polonini, H.C. Toxic elements content of selected industrialized beverages. J. Multidiscip. Eng. Sci. Technol. 2019, 6, 9729-9735.

31. Water Environmental Federation and APH Association. Metals by inductively coupled plasma-Mass spectrometry. In Standard Methods for the Examination of Water and Wastewater; American Public Health Association (APHA): Washington, DC, USA, 2017.

32. Martins-de-Souza, D.; Guest, P.C.; Steiner, J. A proteomic signature associated to atypical antipsychotic response in schizophrenia patients: A pilot study. Eur. Arch. Psychiatry Clin. Neurosci. 2020, 270, 127-134. [CrossRef] [PubMed]

33. Martins-de-Souza, D.; Solari, F.A.; Guest, P.C.; Zahedi, R.P.; Steiner, J. Biological pathways modulated by antipsychotics in the blood plasma of schizophrenia patients and their association to a clinical response. NPJ Schizophr. 2015, 1, 1-7. [CrossRef] [PubMed]

34. OECD—Organisation for Economic Co-operation and Development. Test No. 487: In Vitro Mammalian Cell Micronucleus Test; OECD: Paris, France, 2016.

35. OECD—Organisation for Economic Co-operation and Development. Test No. 423: Acute Oral toxicity-Acute Toxic Class Method; OECD: Paris, France, 2001.

36. EUR-Lex. European Commission regulation (EU) No 1169/2011 of the European Parliament and of the Council of 25 October 2011 on the provision of food information to consumers, amending Regulations (EC) No 1924/2006 and (EC) No 1925/2006 of the European Parliament and of the Council. Off. J. Eur. Union 2011, 304, 18-63.

37. Zaiko, M.V.; Kozin, S.V.; Pavlova, L.A. History and perspectives of medical use raw animal materials on the example of pig spleen drugs. Tradit. Med. 2014, 1, 42-48.

38. European Food Safety Authority. European food safety authority scientific opinion on the safety and efficacy of selenium in the form of organic compounds produced by the selenium-enriched yeast Saccharomyces cerevisiae NCYC R645 (SelenoSource AF 2000) for all species. EFSA J. 2011, 9, 2279. [CrossRef]

39. EFSA. Scientific Opinion on the substantiation of health claims related to zinc and function of the immune system, DNA synthesis and cell division, protection of DNA, proteins and lipids from oxidative damage, maintenance of bone, cognitive function, fertility and reproduction, reproductive development, muscle function, metabolism of fatty acids, maintenance of joints, function of the heart and blood vessels, prostate function, thyroid function, acid-base metabolism, vitamin A metabolism and maintenance of vision pursuant to Article 13(1) of Regulation (EC) No 1924/2006. EFSA J. 2009, 7, 1-34. [CrossRef]

40. European Commission. Discussion Paper on Nutritional Claims and Functional Claims; National Consumer Council: Pretoria, South Africa, 2001.

41. Klann, J.E.; Remedios, K.A.; Kim, S.H.; Metz, P.J.; Lopez, J.; Mack, L.A.; Zheng, Y.; Ginsberg, M.H.; Petrich, B.G.; Chang, J.T. Talin plays a critical role in the maintenance of the regulatory T cell pool. J. Immunol. 2017, 198, 4639-4651. [CrossRef]

42. Fabregat, A.; Sidiropoulos, K.; Viteri, G.; Forner, O.; Marin-Garcia, P.; Arnau, V.; D’Eustachio, P.; Stein, L.; Hermjakob, H. Reactome pathway analysis: A high-performance in-memory approach. BMC Bioinform. 2017, 18, 142. [CrossRef]

43. Desjardins, M. ER-mediated phagocytosis: A new membrane for new functions. Nat. Rev. Immunol. 2003, 3, 280-291. [CrossRef]

44. Salazar-Ramiro, A.; Hernández, P.; Rangel-Lopez, E.; Pérez de la Cruz, V.; Estrada-Parra, S.; Pineda, B. Dialyzable Leukocyte Extract (transfer factor) as adjuvant immunotherapy in the treatment of cancer. MOJ Autoimmune Dis. 2018, 1, 1-7. [CrossRef]

45. Amatya, N.; Garg, A.V.; Gaffen, S.L. IL-17 signaling: The yin and the yang. Trends Immunol. 2017, 38, 310-322. [CrossRef]

46. Kazi, J.U.; Rönnstrand, L. The role of SRC family kinases in FLT3 signaling. Int. J. Biochem. Cell Biol. 2019, 107, 32-37. [CrossRef] [PubMed]

47. Zhang, W.; Liu, H.T. MAPK signal pathways in the regulation of cell proliferation in mammalian cells. Cell Res. 2002, 12, 9-18. [CrossRef] [PubMed] 